\title{
OBITUARIES
}

Prof. A. Wormall, F.R.S.

Arthur Wormall died in St. Bartholomew's Hospital on May 9 at the age of sixty-four. $\mathrm{He}$ will be greatly missed. The high esteem in which he was universally held is aptly epitomized by a remark made some years ago to one of his junior colleagues: "The one thing we envy you most in your department is your professor".

Wormall received his early education at Leeds. graduating in 1921 and joining the staff of the University in 1922. His work as a lecturer and senior lecturer in biochemistry until 1936 can truly be sa:d to have laid the foundations of the Department of Biochemistry which exists in Leeds to-day.

He early developed an interest in problems of immunology; he helped materially to establish the complex nature of hæmolytic complement, and also described the hitherto unrecorded 'fourth component'. His work on proteins modified by nitration, halogenation and treatment with phenyl isocyanate or mustard gas and its derivatives, particularly his original use of correspondingly modified amino-acids as inhibitors of the precipitin reaction between these protein antigens and their specific antisera, work which he commenced as a Rockefellor Medical Fellow working with Landsteiner at the Rockefeller Institute during 1928-29, did much to clarify our present knowledge of the nature of the groupings which determine the immunological specificity of chemically modified proteins.

In 1930-31 he spent a year in Uganda on behalf of the Colonial Office, investigating chemical and immunological problems connected with trypanosomiasis, and developed methods of measuring the persistence of the drug 'Bayer 205' ('Antrypol', 'Germanin') in the blood stream. Although he later carried out work in widely different fields, these two early interests in immunochemistry and trypanosomiasis remained with him all his life.

In 1936 he was appointed to the newly created chair of biochemistry and chemistry in St. Bartholomew's Hospital Medical College (University of London). His great organizing ability, his continual insistence that preclinical biochemistry teaching must be relevant to medicine, and his deep personal interest in all his students and staff, were responsible for the creation of a flourishing department-and a well-beloved chief.

Shortly after he went to 'Bart's', he recommenced work on mustard gas, and during the War led a research group working in Cambridge on the physiological action of mustard gas. It was at this time also that he commenced his work with artificial radioactive isotopes, and he was the first in Britain to use them in biological investigations. It is a tribute to his farsightedness that when he first onvisaged the use of the radioactive sulphur isotope, sulphur-35, in his work on mustard gas, its preparation had been described; but it was stated that its $\beta$-particle emission was too soft for it to be of any use in quantitative investigations. At this time, too, the worker with artificial radioactive isotopes not only had to manufacture his own measuring equipment, but his isotopes also ! Later, when isotopes became more readily available, he extended his use of them to immunological investigations and to investigations on the metabolism of zine in normal and neoplastic tissues. In 1953 he organized and conducted the First Latin-American Course in Radioisotope Methodology, and was awarded an honorar'y doctorate of the University of São Paulo.

He was a governor of the Medical College and of the Hospital, and his wise counsel was greatly valued on tho many College and University committees on which he served.

He was always eager to create opportunities for integrating more closely the work of the Hospital and the preclinical departments, and it 'was mainly due to his endeavours that a research project on the biochemistry of skin was initiated in his Department jointly with the Department of Dermatology in the Hospital.

Wormall had a wide circle of friends, and his gentle courtesy and consideration for others endeared him to all. His great charm of manner readily made the most nervous youngster at ease with him, and no trouble was too great for him to take on behalf of anyone who came to him for help or advice.

Until physical disabilities prevented him, he was a keen golfer, and as a true Yorkshireman had an abiding interest in cricket. His election to the M.C.C. in 1956 probably gave him at least as much pleasure as his election to the Royal Society, which occurred in the same year, and his friends will long remember his account of a day at Lord's with a visiting American scientist when his attempts to explain the rules of the game were frustrated for some time by his visitor's unrealized misconception that the two batsmen were on opposite sides.

In 1925 Arthur Wormall was married to Eva Jackson, who survives him. All his friends would wish to tender to his widow, and his two daughters, their heartfelt sympathy in their loss. $\quad$ G. E. C. Francrs

\section{Mr. H. D. Griffith}

Througr the sudden death of Mr. Harry D. Griffith on April 11, the University of Aberdeen, and the Natural Philosophy Department in particular, lost a member who had given most loyal service for the long period of forty years. Born in 1898 at Clifton, Bristol, he received his early education at Bristol Grammar School and was awarded an open scholarship in 1916. On account of war conditions then in force, this scholarship was not, taken up, but on the cessation of hostilities he entered as a scholar of Trinity College, Cambridge, in 1919 and in due course graduated B.A. Thereafter he continued to work in the Cavendish Laboratory under Sir J. J. Thomson and Sir Ernest Rutherford until 1923. In October of that year he came to Aberdeen on the recommendation of Prof. G. P. Thomson (later Sir Georg, Thomson) with the specific idea of assisting in the teaching of physics to medical students. From this early beginning he was soon engaged in the development not only of tho teaching of physics but also in the installation of a radon supply to hospitals in various parts of the country. In order to accommodate the required apparatus, an addition to the Department was built, and there Mr. Griffith installed towards the end of the 1920 decade the apparatus which enabled a supply of radon to be availablo for hospital work for a period of more than twenty years.

In 1932 he was awarded a Rockefeller Fellowship which enabled him to travel abroad. His first visit was to Berlin. There he studied for some months under Prof. Friedrich at the Institut für Strahlenforschung. Owing, however, to the political upheaval in Germany at that time he found it necessary to leave. From Berlin he went to Stockholm and worked under Prof. Sievert at the Radiumhemmet.

The insight he obtained abroad he put to good use on his return. Soon his services were required by various Departments in the Medical School, and. after the erection of the New Infirmary Buildings at Foresterhill, it was 
found necessary to provide a small laboratory in the Infirmary for his special use. At the same time the personnel required to meet the calls on the medical physics sections gradually increased, the use and direction of which fell very largely on Mr. Griffith.

After the end of the Second World War it became evident that the laboratory accommodation at Foresterhill was insufficient to meet all requirements. As a result it was decided to erect a laboratory fully equipped with research rooms, workshop and office apartments in close contact with the Medical School at Foresterhill. Much of the work in connexion with this project fell to be carried through by Mr. Griffith.

The development of this laboratory, a considerable undertaking in itself, $h \theta$ carried on along with an ample share in the teaching of both theoretical and practical work in the parent Department of Natural Philosophy. In spite of all, he found time to produce several publications and in consequence was elected a Fellow of the Royal Society of Edinburgh in 1954.

From his entry to the University in 1923 until his death in 1964 he devoted his energies wholeheartedly to the development of his subject. Coming as assistant lecturer, he steadily improved his status to that of reader in medical physies in charge of that division in the University Physics Department. His students held him in the highest regard, and referred affectionately to him always as "Harry". Even those who did not come immediatoly under his care testify to the same warmth of feeling, and all felt that in his death they had lost one who had been their friend.

Furthor evidence of this ability to inspire lasting affection is exemplified by the friendship between him and two men of different nationalities - one a German, Dr. Zimmer, whom he met when he first went to Germany and with whom he continued to work for the rest of his life; the other an Englishman, H. Heckstall-Smith, who has recounted in his book, The Doubtful School-Master, his first encounter with $H$. D. Griffith in the Cavendish Laboratory, an encounter which led to a life-long reciprocal exchange of ideas and outlooks. When he came to Aberdeen, he met, in the Natural Philosophy Department, Miss J. M. Jack, herself an honours graduate in physics. A friendship grew up rapidly between them, and in 1927 they were married. They have one daughter who graduated with honours in physies. A. E. M. GEDDES

\section{NEWS and VIEWS}

Max Planck Medallists of the German Physical Society: Prof. G. E. Uhlenbeck and Prof. S. A. Goudsmit

Prof. George E. Uhlenbeck and Prof. Samuel A. Goudsmit have been awarded the Max Planck Medal of the German Physical Society. This gold medal, ono of the highest awards in international science, was conferred on the 106th anniversary of the birth of Planck, the great pioneer of modern physics. Profs. Uhlenbeck and Goudsmit, in 1925, discovered the 'spin of the electron', a cornerstone of present atomie theory. Dr. Goudsmit is also deputy chairman of the Department of Physics in the Brookhaven National Laboratory and managing editor of the American Physical Society. Both scientists received their education in The Netherlands, and joined the faculty of the University of Michigan in 1927. Prof. Uhlenbeck went to the Rockefeller Institute in 1961. Dr. Goudsmit joined the Brookhaven National Laboratory in 1948 and has been a visiting professor in the Rockefeller Institute since 1957. During the Second World War both were connected with radar research in the Massachusetts Institute of Technology. Dr. Goudsmit, moreover, was the scientific head of a secret intelligence mission which moved in with Allied troops and reported, in the winter of 1944, that German scientists had failed to make any significant progress in their work on atomic explosives.

\section{Chemistry in the University of East Anglia :}

Prof. S. F, Mason

DR. S. F. Mason has been appointed profossor of chemistry in the new University of East Anglia at Norwich. Dr. Mason, who is forty years of age, was educated at the Wyggeston Grammar School, Leicester, and Wadham College, Oxford; he graduated with first-class honours in chemistry in 1945, and obtained his M.A. and D.Phil. in 1947. During 1947-53 Dr. Mason was tutor in chemistry at Wadham Colloge and departmental domonstrator in the Museum for the History of Sciences at Oxford; during this period he published a number of papers on the history of scionces and a successful book, A History of the Seiences, which has been translatod into French, German and Japanese. In 1953 he was appointed Research Fellow in the Department of Medical Chemistry of the Australian National University, then housed in London, where he worked on the ultra-violet and infra-red spectroscopy of heterocyclic compounds. In 1956 he was appointed lecturer in chemistry in the
University of Exeter, where he became a senior lecturer in 1961 and reader in chemical spectroscopy in 1963. During his time in Exeter, Dr. Mason published many papers in the fields of spectroscopy, and its application to structural problems, and in theoretical chemistry; during the past two years he has taken up the investigation of optical rotatory power, particularly circular dichroism and optical rotatory dispersion, in which field, too, he has published a number of important papers. Dr. Mason will take up his new appointment on October 1.

\section{Water Resources of England and Wales}

A Water Resources Board is being set up under the Water Resources Act, 1963, and will have the task of advising the Minister of Housing and Local Government on water policy in England and Wales. Its main practical tasks will be to build up comprehensive information about water resources and demands, to work out action needed to augment resources, to secure the promotion of schemes which it recommends and to commission and supervise research. The Board's permanent offices will be outside London, probably in Reading, although at the outset it will operate from Government offices in London. Twentynine new river authorities, also set up under the 1963 Act, will supersede existing river boards and will have important new functions relating to the management of water resources, including a licensing control of abstractions and impoundings of water. Statutory consultations about the size and composition of these authorities, which will have a membership of between 21 and 31, and will be the executive arm of the new system, are now going on.

The following have been appointed members of the newly formed Water Resources Board: Chairman, Sir William Goode, until recently Governor and Commanderin-Chief, North Borneo; Deputy Chairman, Mr. A. G. McLellan, general manager, Sunderland and South Shields Water Co.; Members, Mr. R. A. Banks, until recently a director of Imperial Chemical Industries, Ltd.; Prof. H. C. Darby, professor of geography, University College, London, and until recently a member of the National Parks Commission; Dr. Idris Jones, a former member of the Welsh Advisory Water Committee and lately directorgeneral of research, National Coal Board; Mr. W. A. Muddell, chairman of the Executive Council of the River Boards' Association; Mr. N. A. F. Rowntree, consulting engineer (full-time director of the Board's activities). 